\title{
YouTube as an Airlines Marketing Tool
}

\author{
Martina Pásková1 / Jan Hruška² / Josef Zelenka ${ }^{1}$ \\ e-mail: martina.paskova@uhk.cz, jan.hruska.3@uhk.cz, josef.zelenka@uhk.cz \\ ${ }^{1}$ Department of Recreology and Tourism, Faculty of Informatics and Management, University of Hradec \\ Králové, Hradec Králové, Czech Republic \\ ${ }^{2}$ Department of Economy, Faculty of Informatics and Management, University of Hradec Králové, Hra- \\ dec Králové, Czech Republic
}

Pásková, M., Hruška, J., \& Zelenka, J. (2018). YouTube as an Airlines Marketing Tool. Czech Journal of Tourism, 7(1), 45-69.

DOI: $10.1515 /$ cjot-2018-0003.

\begin{abstract}
Multimedia communication through social media has been experiencing constantly growing significance in the field of airline marketing. The aim of the research presented in this paper was to find out and, with the help of both qualitative and quantitative analyses, describe the way YouTube is used by airlines. The research was conducted in the form of a comparative study with the objective of identifying the difference between YouTube performance of full-service carriers (FSCs) and low-cost carriers (LCCs). The intention was to identify which factors influence the effectiveness of airline marketing conducted via YouTube an as well as the way in which they do it. Analysis of selected data was facilitated by social media analytics tool SocialBakers, content analyses and a correlation analysis of YouTube metrics, selected on the base of previous research results. The research data were collected twice during the year 2017 in order to reflect changes over time. Research results showed that FSCs build their YouTube channels more systematically than LCCs. FSCs offer a substantially wider range of video topics and often sort out topics of their videos in a more detailed way. Regarding the basic metrics of YouTube channels (total number of views, number of subscribers), FSCs surpass LCCs significantly. One reason for their much higher rate of views is the fact that FSCs use celebrities more frequently, and frequently they offer high-quality impression/ relationship airline presentation.
\end{abstract}

\section{Keywords}

low-cost carriers, full-service carriers, social media, YouTube, viral marketing

JEL classification: M31, L28 


\section{Introduction}

Social media are changing the way in which people create, share, and consume information (Khan \& Vong, 2014). Social media as a tourism megatrend is currently used by nearly all tourism actor's groups and have a significant impact on the decision-making of tourism participants, tourism management and on-going activities (Leung et al., 2013). Social media are used particularly to share tourism related knowledge (Munar \& Jacob-

Figure 1 Mental map of social media influence on tourism

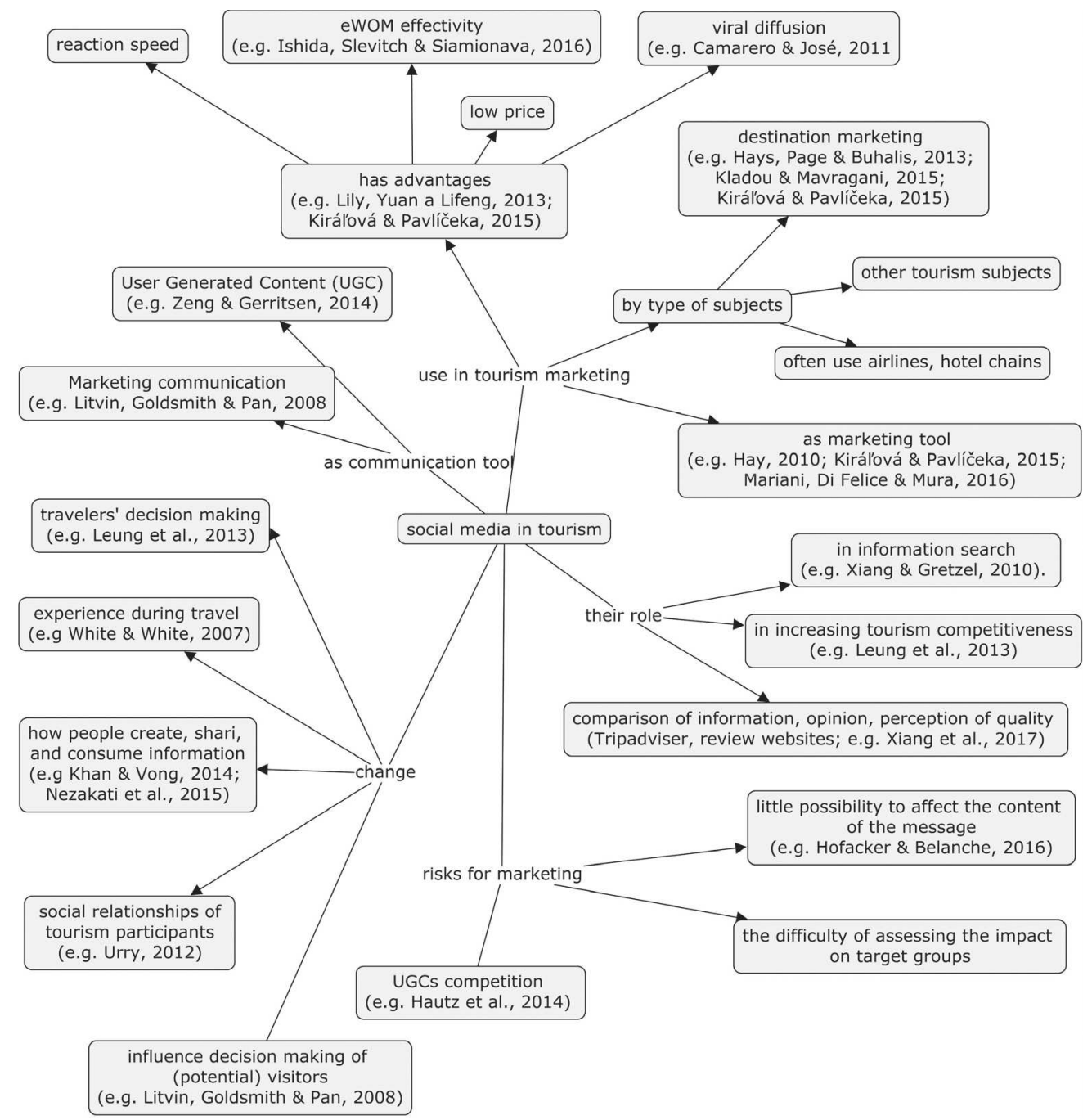

Source: own processing based on sources, cited in mental map 
sen, 2014; Nezakati et al., 2015), information search (Zeng \& Gerritsen, 2014; Mukherjee \& Nagabhushana, 2016; Felix, Rauschnabel, \& Hinsch, 2017), compare and gather information (Xiang \& Gretzel, 2010; Pan \& Crotts, 2012; Law, Buhalis, \& Cobanoglu, 2014; Zeng \& Gerritsen, 2014; Királová \& Pavlíčeka, 2015; Nezakati et al., 2015), strategic marketing (Felix, Rauschnabel, \& Hinsch, 2017), and in communication among tourism actors (Alizadeh \& Isa, 2014, 2015). This kind of communication and information management links social media to tourism marketing on various levels and generates significant changes in it. Social media brings many challenges for marketing managers not only in the tourism sector (openness of marketing, decrease in control level of communication content etc.; e.g., Miguéns, Baggio, \& Costa, 2008; Hofacker \& Belanche, 2016). Social media has become an important part of marketing for both tourism operators and destination managers (Hays, Page, \& Buhalis, 2013; Lily, Yuan, \& Lifeng, 2013; Zeng \& Gerritsen, 2014; Királová \& Pavlíčeka, 2015).

Social media use modifies many facets of tourism, mainly marketing, experience, and communication (Figure 1). Tourism review websites generated by users (e.g., Kladou \& Mavragani, 2015; Xiang et al., 2017) and electronic worth of mouth (eWOM) communication (Litvin, Goldsmith \& Pan, 2008; Sotiriadis \& van Zyl, 2013; Zeng \& Gerritsen, 2014; Ishida, Slevitch, \& Siamionava, 2016) represent typical examples of social media employed in tourism practice.

Internet communication aimed at current and potential tourists have dramatically changed in recent years. Related to increases in communication speed, tourism websites show a trend towards communication with users based on multimedia and more generally on graphics (e.g., Dionyssopoulou, Pridezi, \& Mylonakis, 2014). This includes a preference for sharing graphical content in social media (Tussyadiah \& Fesenmaier, 2009; Munar \& Jacobsen, 2014).

Although the marketing relevance of videos in social media is growing, as the analysis in the theoretical part shows, there are no adequate scientific studies available for airlines. This situation motivated the authors to conduct a comparative study of the success factors of the airlines YouTube channels, based on previous pilot research (Zelenka \& Hruška, 2018).

\section{Theoretical basis}

According to Hruška and Pásková (2018), the extent and use of social media in tourism should be studied scientifically. They conclude that in the present globalized world, the need for a deep understanding of the cognitive and psychological aspects of social media is growing. In the context of a process of the tourism transformation to the necessary social needs of the inhabitants in developed countries, Urry (2012) emphasizes the role of social media in the socialization of tourists. The results of the comparative research analysing the studies from the years of 2007 to 2011 (Leung et al., 2013) have demonstrated the strategic importance of social media for tourism competitiveness. The comparative analysis of these studies has also revealed the main topics of social media 
research such as the influence of social media on the decision-making of potential tourism participants and the roles of social media in the promotion, research, and management of tourism.

A constructively realistic approach to multimedia related theoretical background has assisted in achieving a critical view on the basic effects that multimedia systems have on people, knowledge transfer, entertainment, and data processing (Hoogeveen, 1997; Hruška \& Pásková, 2018). Videos are a significant part of social media in general and increasingly affect tourism marketing. Since 2015, according to a statistical web Statista (2017a), 400 hours of video content is loaded on YouTube every minute. According to these statistics, the most watched type of video is a music video, followed by beauty and fashion tips, personal video blogs and educational or instruction videos.

YouTube is an extremely popular social medium with a strong influence on the conscious and unconscious perception of its users and it serves as a marketing tool in the tourism industry (Hay, 2010; Reino \& Hay, 2011; Alexa, 2017; Hruška \& Pásková, 2018). Tussyadiah and Fesenmaier (2009) reported that online-shared videos significantly affect the imagination and daydreaming of their viewers and thus represent a significant mediator or catalyser of both conscious and subconscious motivation to visit the destination (see types of airlines videos in chapter results, including a presentation of destinations and experiences in them). The experience of interacting with online-shared videos on YouTube, as well as its social importance, have predetermined YouTube's potential for viral marketing (e.g., Camarero \& José, 2011; Khan \& Vong, 2014; Hruška \& Pásková, 2018).

Music videos have the highest potential for viral sharing, and true story videos, celebrity videos, and others may achieve 100 million views in less than ten days (Statista, 2017b). The effectiveness of viral spreading is strongly influenced by the person's integration in the social network, their relationships inside it and their relation to the shared content (Camarero \& José, 2011). According to them, the effectiveness of YouTube video spreading is to give them +/- assessments, add comments to the video and the YouTube recommendation system also has influence, related to the user's former activities. As Khan's (2017) research indicates, among the most important motivations of passive YouTube users are relaxation, entertainment (affirmed by Statista, 2017a; for the case of music video preferences), and reading other user's comments. In order to assess YouTube users' marketing activities, it is necessary to consider users' motivation and activities. According to Khan (2017), it is typical for a group of users looking for information that they enter popularity of approval rating of videos and comment on them but they neither share videos nor upload their own.

Which type of videos do users prefer for destination-oriented videos - user-generated videos (UGVs) or agency-generated videos (AGVs)? Hautz et al. (2014) give evidence that social network users do not significantly prefer UGVs to AGVs. At the same time, they pointed out the quality of videos - in case of high-quality videos, there is no significant difference in social network users' preferences, and on the other hand, in case of lowquality videos users prefer UGVs. 


\section{Methodology}

Systematic, long-term quality marketing with a wide use of ICT and social media is typical for both airlines providing all service (Full Service Carriers - FSCs) and low-cost carriers (LCCs). Among social media, YouTube was chosen for this research as the most favoured social network for sharing and watching videos and the second most frequently visited website (Alexa, 2017; as of 1 May 2017). Particular attention was paid to the quantification of the effectiveness of airlines' communication on YouTube (finding the appropriate metrics) and the factors of this effectiveness. As a part of this work, special research was conducted to test if a number of uploaded videos regardless of their content is one of the factors for YouTube channel success (Zelenka \& Hruška, 2018). Results of this research have not indicated any statistically significant correlation between the number of daily uploaded videos as well as their total number on YouTube channel and user interactions such as likes, dislikes, and comments.

As a continuation of the above-mentioned research (Zelenka \& Hruška, 2018), this study focuses on the way airlines' YouTube channel videos are presented and their typical features, their success rate measured by the number of views, as well as on the factors affecting this success rate. This research also enabled identification of differences in both presenting style and success rate between FSCs and LCCs. To create a conducive research framework, the following research questions were formulated:

What is the typical content of airlines' YouTube channel videos of FSCs and LCCs? How can be videos on airlines' YouTube channels typologized according to their content?

Which airlines marketing needs do those videos satisfy?

Which types of videos do airlines YouTube channel users prefer?

Which airlines are the most successful in addressing YouTube users and why?

What is the difference in using YouTube between FSCs and LCCs?

Which indicators enable description of effectiveness of an airline YouTube channel?

As the research sample for the quantitative analysis, the following airlines YouTube channels were selected on the base of the total number of views of videos placed on the given airlines YouTube channel:

- Five most frequently watched FSCs video channels (with the airline abbreviation as it is used by IATA, 2017): KLM Royal Dutch Airlines, shortly KLM (KL), Turkish Airlines (TK), Air France (AF), Emirates (EK), and LATAM Airlines (LA).

- Five most frequently watched LCCs video channels: WestJet (WS), AirAsia (AK), Pegasus Airlines (PG), SpiceJet (SG), and JetBlue (B6).

To examine the selected research sample of FSCs and LCCs YouTube channels, following research strategies and methods were employed: 
- content analysis for categorization of airlines' YouTube channel videos (the entire content of hundreds of videos of the each selected airline YouTube channel has been; the videos typologization was inspired by the categorizations of individual airlines),

- quantitative content analysis was used on classified types of videos on all selected FSCs and LCCs YouTube channels, and for analyse of occurrence of classified types of videos between 5 most watched videos on all chosen FSCs and LCCs YouTube channels (which types of videos are preferred by users?),

- quantitative research analysing data using Socialbakers analytical software; data obtained from this analysis were clustered on the base of similar quantitative characteristics,

- correlation analyses conducted with the help of statistical software IBM SPSS Statistics assisted in identifying regularity and interdependence in data.

In order to elaborate more precise typology of videos and conduct detailed research of the video portfolio, additional criterion for airlines to be included into the research sample was the number of transported passengers, as referred by IATA (2016). The research sample was thus supplemented with six FSCs (American Airlines - AA, Delta Air Lines - DL, United Airlines - UA, China Southern Airlines - CZ, Lufthansa - LH, British Airways - BA) and two LCCs (Southwest Airlines - WN a Ryanair - FR).

During the process of videos' categorization, not only was their content taken into account, but also the main features that should attract the viewer's attention and motivate him/her to participate in tourism activities, to select a destination, and to create an emotional relationship. Such an attribute was typically a celebrity featuring in an otherwise trivial plot of the video.

In creating clusters, ten companies according to the total number of views of their YouTube channel videos were selected, independently grouped via strict partition clustering, a method of connectivity-based clustering, into three groups according to number of views, number of subscribers, and number of video topics covered. The overlap of these groups is plotted in Figure 5. For this analysis, the data elaborated by social media software Socialbakers were employed. In order to determine which factors considerably affect YouTube performance and how the specific type of videos push people to interact, the Pearson correlation statistical method was applied.

Socialbakers is considered one of the best tools for social media tracking and analysing. It allows the addition of profiles from the biggest social media such as Facebook, YouTube, Twitter or Instagram. Profiles are specific to a Facebook group or YouTube channel. Socialbakers can track the profile, containing information such as interactions, the sum of likes, dislikes, comments, the sum of published videos, dislikes and likes rate, total viewed time, the total number of video views, and an average number of interactions per 1,000 subscribers per period. All of the data can be compared with another added profile. Socialbakers can track and analyse information in user-selected time. Interactions on social media, especially on YouTube are likes, dislikes, and comments. 
The analysis was carried out in the following, successive steps:

- On May 1, 2017, a categorization of videos displayed on YouTube channels of selected airlines was drawn up (Table 1).

- On May 20, 2017, an analysis was carried out on:

- the occurrence of the selected video types on YouTube channels of all the examined FSCs and LCCs (Table 2, Table 3 and Figure 2);

- video types represented among the five most favourite videos watched on the Youtube channels of each of selected airlines (Figure 3);

- specially developed indicator E (more details see discussion, Table 7).

- For the period between 28th May 2016 and 28th May 2017, selected parameters of the metrics of the five most favourite FSCs YouTube channels and the five most favourite LCCs YouTube channels were calculated (Table 5). These parameters were statistically assessed for the same period with the help of Pearson correlations (Table $6)$. The limitation up to 10 airline YouTube Channels is determined by the terms of use of Socialbakers.

- In June 2017 and December 2017, an analysis was carried out on:

- the basic characteristics of the YouTube video portfolio of all the selected FSCs and LCCs, the purpose of which was, in addition to acquiring quantitative portfolio characteristics, detection of any changed dynamics (Table 4);

- the most favoured types of video on YouTube channels of the all the selected FSCs and LCCs (their absolute viewer rating, Figure 4), the results of this analysis include the users' preferences and also detection of changes in the representation of these most favoured videos on Youtube channels of the all the selected FSCs and LCCs.

\section{Results}

This research shows the categorization of airlines YouTube channel videos including a description of their typical contents. The airlines marketing needs satisfied by those videos as well as the airlines YouTube user's preferences of videos types are identified. The research outcomes also offer a list of airlines with the most successful YouTube performance including the success factors. The description of the means by which YouTube is utilized by FSCs and LCCs reveals some significant differences between these two airline types. Finally, the indicators facilitating description of the effectiveness of an airline YouTube activity are identified.

\section{Video typology}

On YouTube, 19 different types of airlines videos were determined. In addition to their content, the videos may also differ in their typical length and in the concept of their processing. The description of the determined types is provided in Table 1 . The types 
'destinations' and 'activities in destinations' are related to the motivation of different visitors' segments to choose a route to a concrete destination.

Table 1 Types of airlines videos and their basic characteristics, May 2017

\begin{tabular}{|c|c|c|}
\hline Type of video & Typical content & $\begin{array}{l}\text { A typical range of } \\
\text { video length } \\
\text { [sec] }\end{array}$ \\
\hline $\begin{array}{l}\text { impression/relationship } \\
\text { airline presentation (IRAP) }\end{array}$ & $\begin{array}{l}\text { emotional introduction of a company, based on } \\
\text { a short projection of services provided, aircrafts, } \\
\text { destinations }\end{array}$ & $30-60$ \\
\hline the history of the airline & $\begin{array}{l}\text { tradition, historical services, connection or } \\
\text { comparison to current services, }\end{array}$ & 120 \\
\hline company introduction & summary of basic facts about the airline & $60-120$ \\
\hline destinations & $\begin{array}{l}\text { presentations of destinations as a set of } \\
\text { attractions }\end{array}$ & $30-120$ \\
\hline activities in destinations & activities and experiences offered by destinations & $20-180$ \\
\hline $\begin{array}{l}\text { the experiences of } \\
\text { travellers in destinations }\end{array}$ & $\begin{array}{l}\text { Focused on the immediacy of the destinations } \\
\text { visitor experience, on their own testimony }\end{array}$ & $20-240$ \\
\hline safety & $\begin{array}{l}\text { very creative safety-related situations (usually, } \\
\text { presentation of safety rules on board) }\end{array}$ & $30-180$ \\
\hline the quality of services & diversity and quality of services & $60-300$ \\
\hline $\begin{array}{l}\text { games and entertainment } \\
\text { for passengers }\end{array}$ & an offer of games and entertainment on board & 60 \\
\hline $\begin{array}{l}\text { experiences of airline } \\
\text { passengers }\end{array}$ & $\begin{array}{l}\text { experiences and comments on services on } \\
\text { board, demonstrations of the use of airline } \\
\text { services from personal point of view }\end{array}$ & $20^{*}$ and 240 \\
\hline service technology & $\begin{array}{l}\text { explaining service technology - aircrafts, check-in } \\
\text { at airports }\end{array}$ & $60-240$ \\
\hline airline social responsibility & $\begin{array}{l}\text { the way of providing services is linked to } \\
\text { presenting often }\end{array}$ & $100-420$ \\
\hline advertising campaigns & targeted at the topical offer & $60-120$ \\
\hline $\begin{array}{l}\text { benefits provided to } \\
\text { a customer }\end{array}$ & $\begin{array}{l}\text { an offer of frequent flyer programs, airlines clubs, } \\
\text { a luxury of travelling in different travel classes }\end{array}$ & $60-120$ \\
\hline celebrities & $\begin{array}{l}\text { celebrities' activities or competitions on board or } \\
\text { famous destinations }\end{array}$ & $45-60$ \\
\hline music/music clips & $\begin{array}{l}\text { music clips, music festivals, music offer in } \\
\text { destinations }\end{array}$ & $60-600$ \\
\hline life stories & $\begin{array}{l}\text { common people - their life story, often linked } \\
\text { through their wishes and dreams to famous } \\
\text { destinations and travelling in general }\end{array}$ & $120-240$ \\
\hline
\end{tabular}




\begin{tabular}{|l|l|c|}
\hline \multicolumn{1}{|c|}{ Type of video } & \multicolumn{1}{|c|}{ Typical content } & $\begin{array}{c}\text { A typical range of } \\
\text { video length } \\
\text { [sec] }\end{array}$ \\
\hline travel tips & $\begin{array}{l}\text { Ideas on where to travel, and tips on how to } \\
\text { avoid problems }\end{array}$ & $30-120$ \\
\hline employees and job offer & $\begin{array}{l}\text { the topic of employees sometimes mingles with } \\
\text { impression/relationship airline presentation }\end{array}$ & $180-240$ \\
\hline
\end{tabular}

*short video version

Source: YouTube (2017a - 2017d, 2017f, 2017k - 2017r)

Table 2 Incidence of video types for FSCs (FSCs names are in IATA codes), as of 20th May 2017

\begin{tabular}{|l|c|c|c|c|c|c|c|c|c|c|c|}
\hline \multirow{2}{*}{\multicolumn{1}{|c}{ video type }} & \multicolumn{9}{|c|}{ FSCs airline } \\
\cline { 2 - 13 } & KL & TK & AF & EK & LA & AA & DL & CZ & UA & LH & BA \\
\hline airline social responsibility & 1 & 0 & 1 & 1 & 0 & 0 & 0 & 0 & 1 & 1 & 0 \\
\hline history of the airline & 1 & 0 & 1 & 1 & 1 & 0 & 0 & 0 & 0 & 0 & 1 \\
\hline safety & 1 & 0 & 1 & 1 & 1 & 1 & 1 & 0 & 1 & 1 & 0 \\
\hline company introduction & 1 & 1 & 0 & 1 & 1 & 1 & 1 & 0 & 1 & 1 & 0 \\
\hline impression/relationship airline & & & & & & & & & & & \\
presentation & 1 & 1 & 1 & 1 & 1 & 1 & 1 & 1 & 1 & 1 & 1 \\
\hline celebrities & 1 & 1 & 0 & 1 & 0 & 1 & 1 & 0 & 1 & 1 & 1 \\
\hline life stories & 1 & 1 & 0 & 0 & 0 & 0 & 1 & 0 & 1 & 1 & 0 \\
\hline advertising campaigns & 1 & 0 & 0 & 0 & 1 & 1 & 0 & 0 & 0 & 0 & 0 \\
\hline destination & 1 & 1 & 1 & 1 & 1 & 0 & 1 & 0 & 0 & 1 & 1 \\
\hline music/music clips & 1 & 1 & 0 & 1 & 0 & 1 & 1 & 1 & 0 & 0 & 1 \\
\hline activities in destinations & 1 & 1 & 1 & 1 & 1 & 0 & 1 & 0 & 0 & 0 & 1 \\
\hline service technology & 1 & 1 & 1 & 1 & 0 & 1 & 1 & 0 & 1 & 1 & 1 \\
\hline quality of service & 1 & 1 & 1 & 1 & 1 & 1 & 1 & 1 & 1 & 1 & 1 \\
\hline experiences of airline passengers & 1 & 1 & 1 & 1 & 1 & 0 & 0 & 0 & 1 & 0 & 1 \\
\hline customer benefits & 1 & 0 & 1 & 1 & 1 & 1 & 1 & 0 & 1 & 1 & 1 \\
\hline games and entertainment for passengers & 1 & 0 & 1 & 0 & 0 & 0 & 0 & 0 & 0 & 0 & 1 \\
\hline travel tips & 1 & 0 & 0 & 0 & 1 & 0 & 1 & 0 & 0 & 0 & 0 \\
\hline the experiences of travellers & 0 & 1 & 1 & 1 & 0 & 1 & 0 & 0 & 0 & 1 & 1 \\
\hline employees and job offers & 0 & 0 & 1 & 1 & 0 & 0 & 0 & 0 & 0 & 0 & 0 \\
\hline total occurrence of video types & 17 & 13 & 15 & 11 & 10 & 12 & 3 & 10 & 11 & 12 \\
\hline
\end{tabular}

Source: YouTube (2017a - 2017d, 2017f, 2017k - 2017r), IATA (2017). 
KLM YouTube channel (code KL) offers all the video types except those two 'relating the experiences of travellers' and 'employees and job offers'. The same pay for Emirates (code EK) but it does not offer also 'life stories' and 'advertising campaigns'. China Southern Airlines (code CZ) provide the less amount of video types, which offers just 'impression/relationship airline presentation', 'music/music clips' and 'quality of service'. The complete incidence of FSCs video types is described in Table 2. The same is provided for LCCs video types in Table 3.

Table 3 Incidence of video types for LCCs (LCCs names are in IATA codes), as of 20th May 2017

\begin{tabular}{|l|c|c|c|c|c|c|c|}
\hline \multirow{2}{*}{\multicolumn{1}{|c|}{ video type }} & \multicolumn{7}{c|}{ LCCs airline } \\
\cline { 2 - 9 } & WS & AK & PC & SG & B6 & FR & WN \\
\hline airline social responsibility & 0 & 0 & 0 & 0 & 1 & 0 & 1 \\
\hline history of the airline & 1 & 0 & 0 & 0 & 0 & 0 & 0 \\
\hline safety & 0 & 0 & 1 & 0 & 0 & 0 & 0 \\
\hline company introduction & 0 & 0 & 0 & 0 & 1 & 1 & 1 \\
\hline impression/relationship airline presentation & 1 & 1 & 1 & 1 & 1 & 1 & 1 \\
\hline celebrities & 0 & 1 & 0 & 0 & 1 & 0 & 0 \\
\hline life stories & 1 & 0 & 0 & 0 & 1 & 0 & 1 \\
\hline advertising campaigns & 0 & 1 & 1 & 1 & 0 & 1 & 0 \\
\hline destination & 1 & 1 & 1 & 0 & 1 & 1 & 0 \\
\hline music/music clips & 0 & 0 & 0 & 1 & 1 & 0 & 1 \\
\hline activities in destinations & 1 & 1 & 0 & 0 & 0 & 1 & 0 \\
\hline service technology & 1 & 1 & 0 & 0 & 0 & 1 & 1 \\
\hline quality of service & 1 & 0 & 0 & 1 & 0 & 0 & 0 \\
\hline experiences of airline passengers & 0 & 0 & 0 & 0 & 0 & 1 & 0 \\
\hline customer benefits & 1 & 0 & 0 & 0 & 1 & 0 & 1 \\
\hline games and entertainment for passengers & 0 & 1 & 0 & 0 & 0 & 0 & 0 \\
\hline travel tips & 0 & 1 & 0 & 0 & 1 & 0 & 0 \\
\hline the experiences of travellers & 1 & 1 & 1 & 0 & 0 & 0 & 1 \\
\hline employees and job offers & 10 & 9 & 5 & 4 & 9 & 7 & 8 \\
\hline total occurrence of video types & & 0 & 0 & 0 & 0 & 0 \\
\hline
\end{tabular}

Source: YouTube (2017e, 2017g, 2017h - 2017j, 2017n, 2017r), IATA (2017)

Analysis of the incidence of individual video types at FSCs and LCCs YouTube channels provided following observations:

- Substantially more topics on average are offered by the selected FSCs (11) than LCCs (7). The highest number of topics is offered by FSCs KLM (17 from total 19), and 
Emirates (14), followed by other FSCs Air France, Delta Airlines and British Airways (all three 12 topics).

- All the analysed companies have built their image by means of an impression/relationship airline presentation, aimed at establishing an emotional relationship with the airline. There are also no differences between FSCs and LCCs in offering videos about destinations ( $72 \%$ of all airlines), the experiences of travellers $(56 \%)$, and life stories $(44 \%)$

- There are substantial differences between FSCs and LCCs in the following topics: service technology FCCs $(82 \%)$ and LCCs (57\%), both music/music clips and activities in destinations FSCs $64 \%$ and LCCs 43\%, both company introduction and customer benefits FSCs $73 \%$ and LCCs 43\%, celebrities FSC 73\% and LCC 29\%, quality of service FSCs $91 \%$ and LCCs $29 \%$.

- Only advertising campaigns and a marginal topic of travel tips were offered more frequently by LCCs than by FSCs.

Figure 2 Comparison of various video types for FSCs and LCCs in percentages of the average number of topics (as of 20th May 2017)

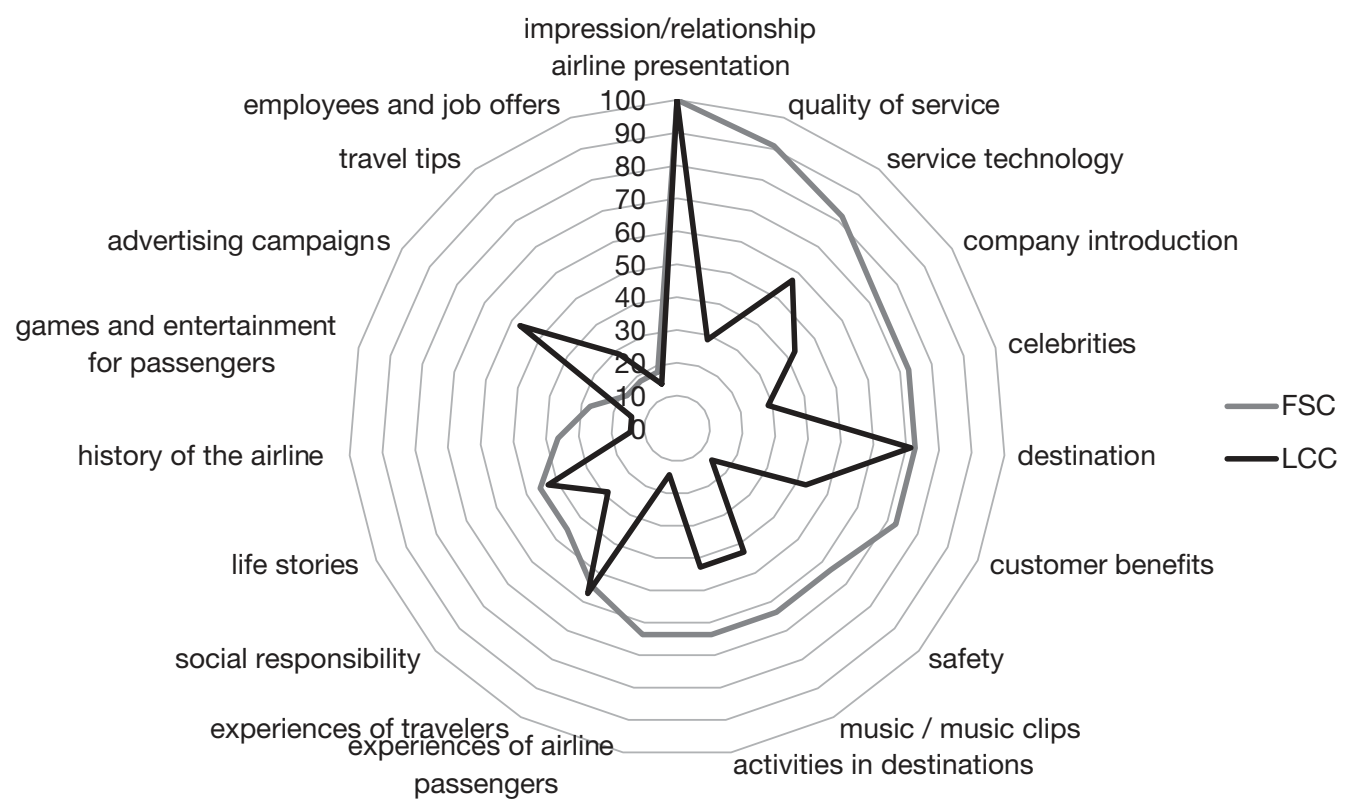

Source: YouTube (2017a-2017s)

\section{Research on airlines video portfolios on YouTube}

The analyses of airlines video portfolios on YouTube revealed dynamics of its basic characteristics including the popularity of individual video types, the distinction of individual airlines as well as between FCCs and LCCs. Detailed data describing these characteristics 
and their changes between June 2017 and December 2017 are available in the Table 4 . A typical phenomenon is a small increase in airlines channels number of videos, but with extreme (doubled) increase of Ryanair numbers. On the contrary, there is a substantial decrease in number of videos of some airlines (Turkish Airlines, Delta Airlines, and AirAsia), because they deleted many of their sparsely watched videos.

Table 4 Basic characteristics of selected airlines video portfolios on YouTube as in June 2017 and December 2017

\begin{tabular}{|c|c|c|c|c|c|c|c|}
\hline \multirow[b]{2}{*}{ Airline } & \multicolumn{2}{|c|}{ Number of } & \multirow{2}{*}{$\begin{array}{c}\text { Total video } \\
\text { views } \\
\text { [mln] }\end{array}$} & \multirow{2}{*}{$\begin{array}{c}\text { Number of } \\
\text { subscribers } \\
\text { [th] }\end{array}$} & \multirow{2}{*}{$\begin{array}{l}\text { Channel } \\
\text { registered } \\
\text { from }\end{array}$} & \multirow{2}{*}{$\begin{array}{c}\text { Oldest } \\
\text { videos } \\
\text { [year] }\end{array}$} & \multirow{2}{*}{$\begin{array}{c}\text { Link } \\
\text { channel } \\
\text { to own } \\
\text { website* }\end{array}$} \\
\hline & Videos & $\begin{array}{l}\text { Video } \\
\text { types }\end{array}$ & & & & & \\
\hline KLM & $549 / 601$ & 17 & $113 / 121$ & $108 / 123$ & 2009 & 8 & 0 \\
\hline Turkish Airlines & $318 / 198$ & 11 & $512 / 594$ & $163 / 210$ & 2006 & 6 & 1 \\
\hline Air France & $421 / 476$ & 12 & $132 / 136$ & $56 / 63$ & 2011 & 5 & 1 \\
\hline Emirates & $417 / 478$ & 14 & $102 / 126$ & $215 / 278$ & 2006 & 5 & 1 \\
\hline LATAM Airlines & $262 / 281$ & 11 & $75 / 80$ & $100 / 110$ & 2005 & 3 & 1 \\
\hline American Airlines & $395 / 441$ & 10 & $13.6 / 14.7$ & $44 / 49$ & 2006 & 8 & 1 \\
\hline Delta Airlines & $369 / 142$ & 12 & $16.7 / 19.7$ & $59 / 64$ & 2006 & 1 & 0 \\
\hline $\begin{array}{l}\text { China Southern } \\
\text { Airlines }\end{array}$ & $20 / 16$ & 3 & $0.1 / 0.1$ & $0.4 / 0.5$ & 2014 & 2 & 0 \\
\hline United Airlines & $164 / 191$ & 10 & $8 / 10$ & $26 / 32$ & 2006 & 5 & 1 \\
\hline Lufthansa & $321 / 341$ & 11 & $26 / 46$ & $36 / 44$ & 2006 & 7 & 1 \\
\hline British Airways & $381 / 415$ & 12 & $45 / 69$ & $91 / 134$ & 2009 & 6 & 0 \\
\hline WestJet & $381 / 419$ & 9 & $92 / 96$ & $62 / 65$ & 2006 & 7 & 0 \\
\hline AirAsia & $799 / 275$ & 9 & $62 / 64$ & $57 / 58$ & 2006 & 6 & 1 \\
\hline Pegasus Airlines & $184 / 216$ & 5 & $34 / 75$ & $12 / 16$ & 2010 & 7 & 1 \\
\hline SpiceJet & $81 / 98$ & 4 & $32.2 / 32.9$ & $7 / 10$ & 2009 & 7 & 0 \\
\hline JetBlue & $170 / 178$ & 9 & $14.4 / 16.6$ & $18 / 21$ & 2006 & 6 & 1 \\
\hline Ryanair & $306 / 618$ & 7 & $10 / 15$ & $17 / 25$ & 2012 & 1 & 1 \\
\hline $\begin{array}{l}\text { Southwest } \\
\text { Airlines }\end{array}$ & $566 / 544$ & 8 & $7 / 10$ & $23 / 52$ & 2007 & 9 & 1 \\
\hline
\end{tabular}

Legend: * 0/1 not linked/ linked to the own airline website; data before slash are 25th June 2017, data after slash are 31st December 2017; LCCs grey fields.

Source: YouTube (2017a - 2017s), Socialbakers (2017a), airlines web pages 
Creating an overview of the most popular types of airline videos on YouTube (Figure 3 - proportional representation) is based on the overall assessment of the five most popular types of videos on YouTube of each airline. Impression/relationship airline presentation is clearly dominant, as its share among the top five types of videos equals $31 \%$ (see also Figure 2 - this topic is represented in all airlines). Other strong topics with the share of about $10 \%$ are service technology, life stories, quality of service, celebrities, and customer benefits.

Figure 3 The most popular types of airline videos on YouTube (as of 20th May 2017), according to their relative frequency of presence among the top five videos on each airline YouTube channel

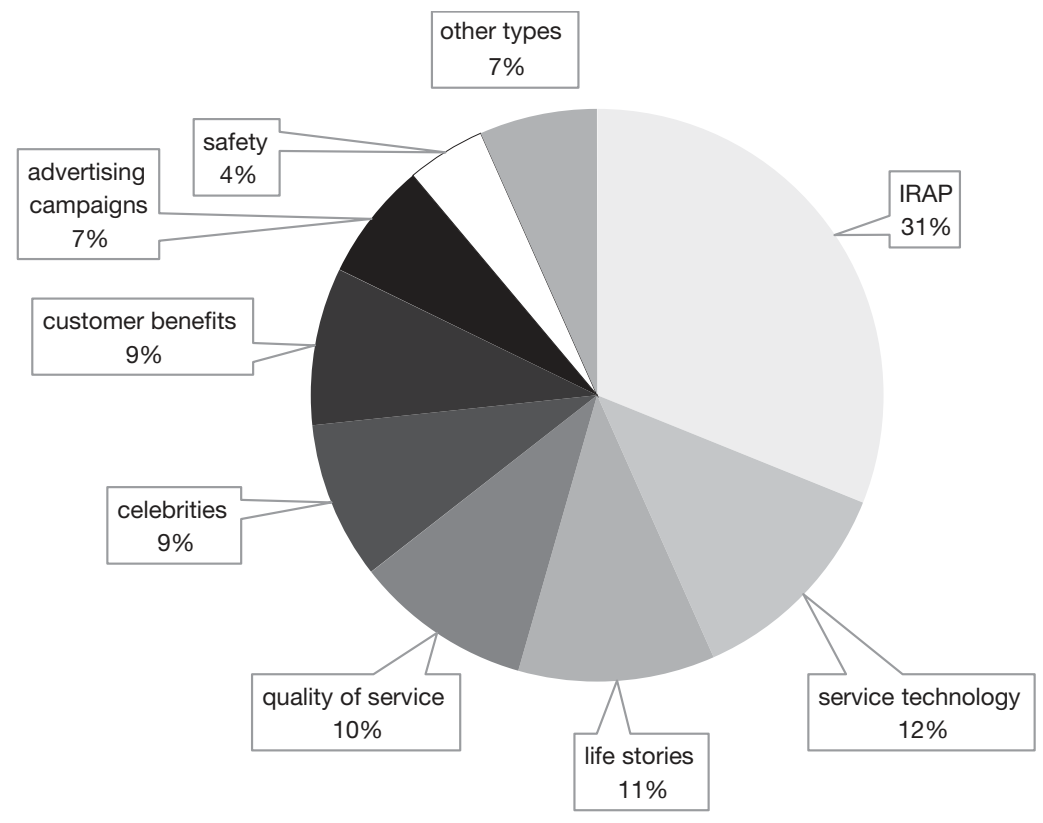

Source: own research

The indicator concerning the viewer ratings of the most frequently viewed video types in absolute numbers for all airlines together gives more interesting information on social media effectiveness. Its values are shown in Figure 4 (IRAP stands for impression/relationship of airline presentation). Figure 4 clearly shows the popularity of videos featuring celebrities as well as IRAP videos. Other popular types of videos are customer benefits, service technology, life stories, and destinations. These most frequently viewed video types may form a significant part of an airline's total viewer rating. For example, in case of Turkish Airlines two most popular videos make more than $50 \%$ of viewer rating, and the most frequently viewed video of Air France comprises as many as $80 \%$ of the total viewer rating. 
Figure 4 Absolute viewer ratings of the most popular types of airlines videos on YouTube as of 20th May 2017 (light) and 31st December 2017 (dark)

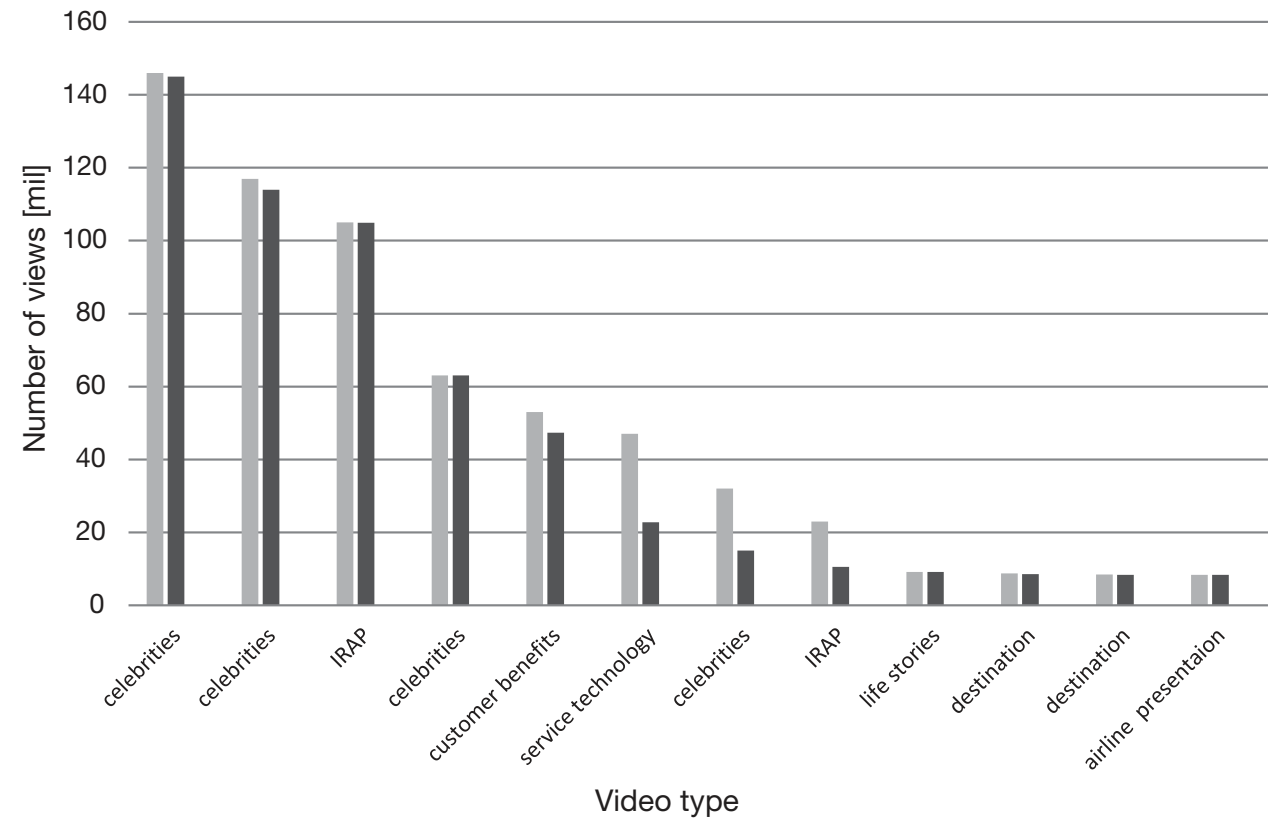

Source: YouTube (2017a-2017s)

The concept, content, and emphasis on individual topics of videos on YouTube as well as the utilization of specific approaches differ among airlines - see the discussion of YouTube channel success rate in chapter Discussion/Correlation summary.

Detailed analysis of YouTube channels for five most popular FSCs and LCCs

Metrics used for studying YouTube channels are the number of videos uploaded by channel, number of subscribers, and that of interactions (that contains likes, dislikes, and comments). Table 5 shows how many subscribers and total views the selected airlines had as of 28th May 2017. Variables, namely the average change of subscribers per day, uploaded new videos per week, and interactions per day, were calculated for the period between 28th May 2016 and 28th May 2017. Table 5 shows that the number of videos is not that relevant to YouTube channel success (subscribers and total uploaded video views). On average, more than one video was uploaded every week to top airlines YouTube channels.

Almost all the examined channels provide their videos in English (with the exception of LATAM Airlines, which use Portuguese). All channels make their videos short; none of the most successful contributions takes over 5 minutes. 
Table 5 Top five FCCs and LCCs (grey cells) according to the number of video views, their YouTube channel metrics. Data for uploaded new videos per week, interactions per day and average change of subscribers per day was calculated from downloaded report (Socialbakers) between 20th May 2016 and 20th May 2017

\begin{tabular}{|l|c|c|c|c|c|c|}
\hline \multicolumn{1}{|c|}{ Airline } & \multicolumn{6}{|c|}{ YouTube channel metrics } \\
\hline & $\begin{array}{c}\text { Number of } \\
\text { videos }\end{array}$ & $\begin{array}{c}\text { Uploaded } \\
\text { new videos } \\
\text { per week }\end{array}$ & $\begin{array}{c}\text { Subscribers } \\
\text { [th] }\end{array}$ & $\begin{array}{c}\text { Interactions } \\
\text { per day }\end{array}$ & $\begin{array}{c}\text { Average } \\
\text { change of } \\
\text { subscribers } \\
\text { per day }\end{array}$ & $\begin{array}{c}\text { Total } \\
\text { uploaded } \\
\text { video views } \\
\text { [mln] }\end{array}$ \\
\hline $\begin{array}{l}\text { Turkish } \\
\text { Airlines }\end{array}$ & 314 & 0.6 & 163.0 & 301 & +77 & 510.3 \\
\hline Air France & 430 & 1.5 & 56.1 & 64 & +30 & 132.2 \\
\hline KLM & 551 & 2.2 & 108.3 & 165 & +67 & 110.8 \\
\hline Emirates & 419 & 1.6 & 212.9 & 450 & +287 & 102.0 \\
\hline WestJet & 398 & 1.4 & 62.0 & 52 & +11 & 92.3 \\
\hline $\begin{array}{l}\text { LATAM } \\
\text { Airlines }\end{array}$ & 199 & 1.7 & 109.3 & 91 & +84 & 79.0 \\
\hline AirAsia & 845 & 5.1 & 57.2 & 90 & +104 & 60.5 \\
\hline $\begin{array}{l}\text { Pegasus } \\
\text { Airlines }\end{array}$ & 187 & 0.6 & 8.8 & 19 & +2 & 32.5 \\
\hline SpiceJet & 83 & 0.6 & 7.0 & 8 & +14 & 32.2 \\
\hline JetBlue & 171 & 0.1 & 18.6 & 12 & +0.1 & 15.5 \\
\hline
\end{tabular}

Source: YouTube (2017a - 2017j), Socialbakers (2017a, 2017b)

In general, videos of companies with a high rate of interactions are created to evoke emotions, such as to awake passion for travel. These airlines show in their videos how easy and comfortable it is to travel, demonstrate the comfort of their services or depict the quality of their planes and other devices.

In Table 6 the Sub_growth variable stands for the total subscriber growth for the last 365 days (between 20 May 2016 and 20 May 2017). Variables interactions and views stand for the total amount of interactions and the total number of views added. All tests are launched on significance level $95 \%$ and between March 2016 and March 2017. The success of any YouTube channel is determined by how much subscribers and other users interact, how people like and comment on the video. The following correlations show to what extent each of the selected airlines was successful in this aspect. 
Table 6 Pearson correlations of chosen parameters of YouTube channel metrics for FSCs and LCCs (grey cells), calculated for period between 20th May 2016 and 20th May 2017

\begin{tabular}{|c|c|c|c|c|c|c|}
\hline Airline & & Interactions & Views & Likes & Dislikes & Comments \\
\hline \multirow{2}{*}{ LATAM Airlines } & Sub_growth & $.993^{\star \star}$ & $.610^{\star \star}$ & $.994^{\star \star}$ & $.994^{\star \star}$ & $.608^{* \star}$ \\
\hline & Interactions & & $.591^{\star \star}$ & $.999^{\star \star}$ & $.999^{\star *}$ & $.654^{\star *}$ \\
\hline \multirow{2}{*}{ Turkish Airlines } & Sub_growth & $.931^{\star \star}$ & $.720^{\star \star}$ & $.919^{* \star}$ & $.954^{* *}$ & $.484^{* *}$ \\
\hline & Interactions & & $.527^{\star \star}$ & $.992^{\star \star}$ & $.918^{\star \star}$ & $.571^{\star \star}$ \\
\hline \multirow{2}{*}{ AirAsia } & Sub_growth & $.794^{\star \star}$ & $.573^{\star \star}$ & $.729^{\star \star}$ & $.838^{\star \star}$ & $.583^{\star \star}$ \\
\hline & Interactions & & $.647^{\star \star}$ & $.969^{\star \star}$ & $.958^{\star *}$ & $.793^{\star \star}$ \\
\hline \multirow{2}{*}{ WestJet } & Sub_growth & $.789^{\star \star}$ & $.812^{\star \star}$ & $.801^{\star \star}$ & $.980^{\star \star}$ & $.236^{\star \star}$ \\
\hline & Interactions & & $.818^{\star \star}$ & $.961^{\star \star}$ & $.752^{\star \star}$ & $.561^{\star \star}$ \\
\hline \multirow{2}{*}{ Emirates } & Sub_growth & $.775^{\star \star}$ & $.778^{\star \star}$ & $.715^{\star \star}$ & $.833^{\star \star}$ & $.577^{\star \star}$ \\
\hline & Interactions & & $.921^{\star \star}$ & $.981^{\star \star}$ & $.900^{\star *}$ & $.776^{\star \star}$ \\
\hline \multirow{2}{*}{ Air France } & Sub_growth & $.486^{\star \star}$ & $.778^{\star \star}$ & $.366^{\star \star}$ & $.831^{\star *}$ & $.157^{\star *}$ \\
\hline & Interactions & &, $441^{\star \star}$ & $.942^{\star \star}$ & $.559^{\star \star}$ & $.467^{\star \star}$ \\
\hline \multirow{2}{*}{ KLM } & Sub_growth & $.484^{\star \star}$ & $.332^{\star \star}$ & $.552^{\star \star}$ & $.473^{\star \star}$ & .054 \\
\hline & Interactions & & $.284^{\star \star}$ & $.915^{\star \star}$ & $.603^{\star \star}$ & $.592^{\star \star}$ \\
\hline \multirow{2}{*}{ SpiceJet } & Sub_growth & $.303^{\star *}$ & $.753^{\star \star}$ & $.237^{\star \star}$ & $.503^{\star \star}$ & .078 \\
\hline & Interactions & & $.181^{\star \star}$ & $.906^{\star \star}$ & $.272^{\star \star}$ & $.493^{\star \star}$ \\
\hline \multirow{2}{*}{ JetBlue } & Sub_growth & $.008^{\star \star \star}$ & .009 & .012 & .038 & -.002 \\
\hline & Interactions & & $.440^{\star \star}$ & $.680^{\star \star}$ & $.429^{\star \star}$ & $.751^{\star \star}$ \\
\hline \multirow{2}{*}{ Pegasus Airlines } & Sub_growth & $0^{\star \star \star}$ & $.458^{\star *}$ & .016 & -.014 & -.009 \\
\hline & Interactions & & $.630^{\star \star}$ & $.999^{\star \star}$ & $.999^{\star \star}$ & $.896^{\star \star}$ \\
\hline
\end{tabular}

Note: *Correlation is significant at the 0.05 level (2-tailed); ${ }^{* *}$ Correlation is significant at the 0.01 level (2-tailed); ${ }^{\star \star \star}$ Correlations for Pegasus Airlines and JetBlue (grey cells) were significantly affected by one-off events

- Pegasus Airlines attract 2400 subscribers a day and JetBlue lost in one day 1900 subscribers.

Source: YouTube (2017a - 2017j), Socialbakers (2017b) 


\section{Discussion}

The outcomes show that the key success factors of airline YouTube videos consist in using emotional aspects (e.g., celebrities) in the video content and relation of this content to the common life of passengers. The reflection and satisfaction of the passengers needs in the video content also play a significant role in the marketing success, as well as does focusing on the quality of the offered services.

Even though Alexa (2017) states that as of 1st May 2017, YouTube was the second most used website, part of the eighteen analysed airlines use YouTube in comparison to Facebook and Twitter as a supplementary social medium for their marketing. As it clearly follows from Table 4, one-third of airlines have no link between YouTube and their website. Figure 5 shows clear differences between the approaches of airlines towards YouTube and their YouTube channels' success rates. The scheme visualizes similar clustering of the number of video types (which is a significant trait of good care of YouTube channels), number of registered video subscribers and the total number of video views.

Figure 5 Airlines hierarchical clusters with similar video presentations metrics on YouTube (Range of topics, Subscribers, Total number of uploaded video views), as of 20th May 2017.

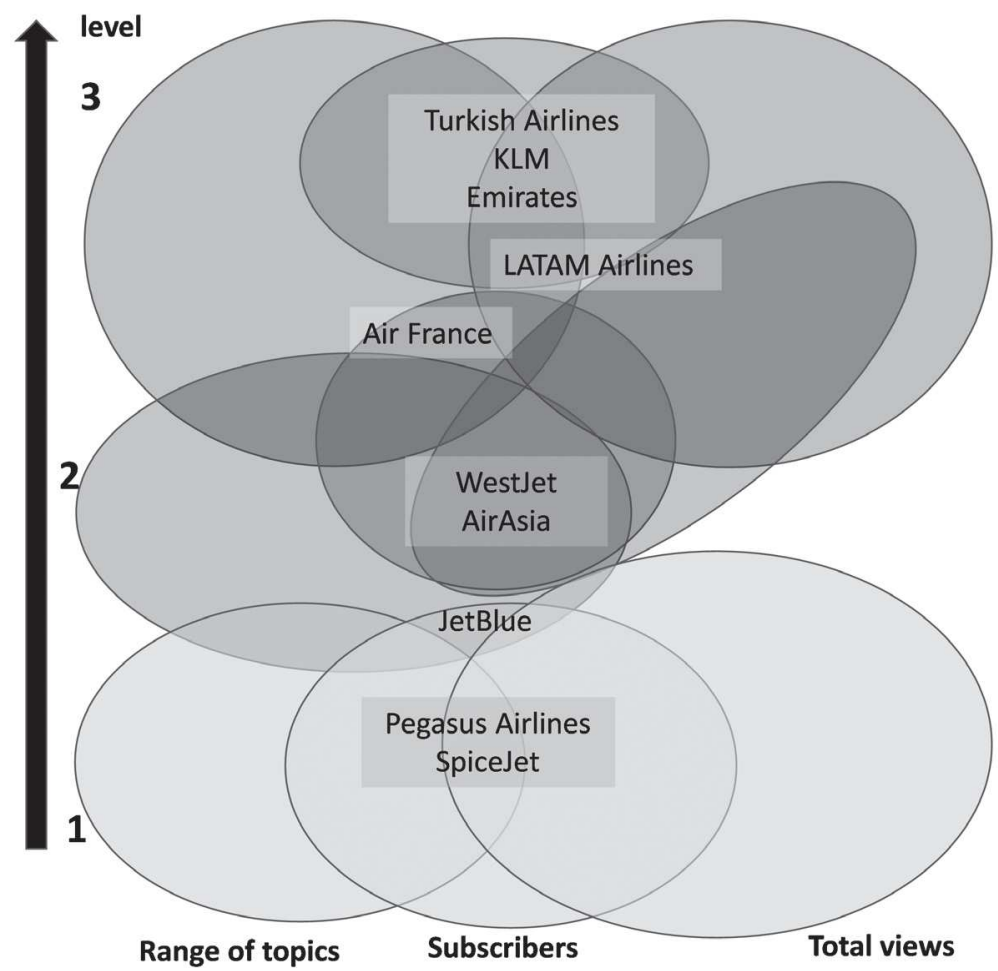

Source: YouTube (2017a - 2017j), Socialbakers (2017a) 


\section{Video contents and typology}

Regarding the typical content of airline YouTube channel videos for FSCs and LCCs, an analysis of eighteen YouTube channels resulted in distinction of the 19 video types, as they are briefly characterized in Table 1, and sorted according to their frequency in Table 2 and Table 3. This typologization is based on the knowledge of quality marketing and typical tourism processes as well as the customers' psychology, including expectations concerning the contents of airlines YouTube channels. The following airline marketing needs were identified. Several topics meet more than one need; (Zelenka \& Hruška, 2018) and were satisfied by various videos types on their YouTube channel:

- Sort of provided services - service technology; safety; quality of service; games and entertainment for passengers,

- Need to establish a relationship with the airline's potential customers - company introduction; impression/relationship airline presentation; customer benefits; airline social responsibility; history of the airline; experiences of airline passengers,

- Knowledge of effectiveness of event marketing (as it is shown by Alagöz \& Ekici, 2014, who analysed Turkish Airlines) -experiences of airline passengers; activities in destinations; the experiences of travellers,

- Advice and support for travellers (emotional, factual, relational) - destination; activities in destinations; travel tips; the experiences of travellers,

- Knowledge of the potential of viral videos with appropriate content (as it was mentioned by Statista, 2017b; music videos, life stories, and videos about celebrities) - airlines channel topics are therefore celebrities; life stories; music/music clips,

- Needs of airlines management including personal management - topic employees and job offers,

- Direct application of marketing communication - topic-advertising campaigns.

In order to assess the success rate of airlines in addressing YouTube users, the applied metrics was based on the total amount of video views on YouTube. These metrics were used as a basis for selecting the portfolio of airline videos for further analyses (see Table 5 and Table 6). Table 4 suggests that the biggest FSCs are rarely the most viewed on YouTube. Among the big airlines, YouTube channels of Emirates and Air France are viewed very frequently. On the contrary, big airlines as British Airways, Lufthansa, Delta Airlines, American Airlines, United Airlines, Southwest Airlines or China Southern Airlines operate without frequently viewed YouTube channels.

Concerning the videos type's preferences by the airlines YouTube channel users, the key success factors, measured through the indicator of the total viewers numbers (Figure 4 and particularly Figure 3), are the inclusion of sports celebrities (football, basketball, baseball) in the video content. The limited duration of the video as well as its composition as an impression/relationship airline presentation are of the same significance. Airlines can also achieve high viewer ratings by inventive videos promoting service technology and quality, customer benefits, safety, and destinations as well as by narrating 
the life stories. The assertion (Statista, 2017b), that videos involving celebrities and life stories have huge viral potential, was confirmed. Another assertion (Statista, 2017b), that music videos have also huge viral potential, was disproved. This is probably caused by the generally low quality of the airlines music videos (as resulted out of the analysis of this research - the considered aspects were the video concept, including the connection of music and the story; the shots quality and the artists' familiarity) and different thematic focus in comparison with the content of the rest of the video types of the airlines YouTube channels.

\section{Comparison of FSCs and LCCs}

The comparison of the way YouTube channels are used by FSCs and LCCs most successfully (which regards their YouTube performance effectiveness) results in the following findings:

- FSCs build their YouTube channels more systematically than LCCs - FSCs, they offer a wider range of video types (Figure 2, Table 2, Table 3) and they usually cluster their video types in a more elaborated way.

- FSCs channels are better developed (Table 2, Table 3, and video types in Figure 2), they show better results in all three significant YouTube channel metrics (Range of topics, Subscribers, Total uploaded video views - clusters in Figure 5, Table 5). Use of celebrities in FSCs videos is the most important factor of their higher viewer ratings than LCCs (see also Figure 4 and users preferences of relaxing entertainment motive as asserted by Khan, 2017).

- Quality of FSCs videos is one of the success factors, which can significantly increase the interactions per one thousand subscribers in comparison with LCCs videos. It means that FCSs videos motivate their viewers to react to comments, likes or dislikes much more intensively than LCCs. This is again compatible with the assertion of significance of the relaxing entertainment motive (Khan, 2017).

The pilot study assumption (Zelenka \& Hruška, 2018), that the total number of videos on YouTube channel is not the decisive factor for the airlines YouTube channel success, was confirmed. In this context, the reduced number of videos on the Turkish Airlines and AirAsia YouTube channels during the 2017 (Table 4) can be significant. The prerequisites for the airlines YouTube channel success lie in selecting the most successful video types (celebrities, impression/relationship airline presentation etc.), applying invention (see catchy safety videos - Emirates), and a suitable way of structuring the channel contents, including the offer of most successful (top) videos. 


\section{The effectiveness of an airline YouTube channel}

Which indicators enable description of the effectiveness of an airline YouTube channel?

The research outcomes reveal that the performance effectiveness of an airline YouTube channel can be measured by indicator titled by authors as ' $E$ '. Values of this indicator are to be calculated with following formula ' $\mathrm{E}=\mathrm{TCW} /(1000 * \mathrm{TCV})$ ', where $\mathrm{E}$ indicates the effectiveness of the YouTube channel video measured by its normalized average views number per one video, while TCW means Total Channel Views, and TCV equals the Total Channel Videos. The Table 7 displays the rankings of the selected airlines according to their value of $\mathrm{E}$ indicator and related metrics. According to data from table 7, the most effective channels are Turkish Airlines, followed by SpiceJet and LATAM Airlines.

Table 7 TCW/TCV metric and ranking for FCCs and LCCs (grey cells) YouTube channels, as of 20th May 2017

\begin{tabular}{|l|c|c|c|c|}
\hline \multirow{2}{*}{ Airline } & TCW ranking & Subscribers & \multicolumn{2}{c|}{ E } \\
\cline { 4 - 5 } & & ranking & absolute & Ranking \\
\hline Turkish Airlines & 1. & 2. & 1611 & 1. \\
\hline Air France & 2. & 9. & 314 & 4. \\
\hline KLM & 3. & 4. & 206 & 7. \\
\hline Emirates & 4. & 1. & 246 & 5. \\
\hline WestJet & 5. & 6. & 243 & 6. \\
\hline LATAM Airlines & 6. & 3. & 350 & 3. \\
\hline AirAsia & 7. & 8. & 78 & 12. \\
\hline British Airways & 8. & 5. & 120 & 9. \\
\hline Pegasus Airlines & 9. & 16. & 189 & 8. \\
\hline SpiceJet & 10. & 17. & 398 & 2. \\
\hline Lufthansa & 11. & 11. & 83 & 11. \\
\hline Delta Airlines & 12. & 7. & 45 & 14. \\
\hline JetBlue & 13. & 14. & 85 & 10. \\
\hline American Airlines & 14. & 10. & 34 & 16. \\
\hline Ryanair & 15. & 15. & 35 & 15. \\
\hline United Airlines & 16. & 12. & 61 & 13. \\
\hline Southwest Airlines & 17. & 13. & 14 & 17. \\
\hline China Southern Airlines & 18. & 7 & 18. \\
\hline
\end{tabular}

Source: YouTube (2017a - 2017r), Socialbakers (2017a, 2017b) 


\section{Correlation summary and success factors}

As shown in Table 6, the correlation of selected YouTube channel metrics with an increasing number of subscribers varies within airlines. When this correlation is strong, new subscribers are strongly motivated (as for LATAM Airlines, Turkish Airlines, AirAsia, WestJet, and Emirates) to react to a video comment, a like, or dislike (which is a summary of channel interactions). That means that the behaviour of users can vary within various YouTube channels, which is related to their content and the mentality of the target group. This is documented by the following examples.

LATAM Airlines and Turkish Airlines' have very strong correlations and AirAsia, WestJet and Emirates have strong positive correlations between subscriber growth and interactions as well as likes and dislikes. That means that new subscribers are very active on the channel (interactions) and are adding likes and dislikes very fast (strong YouTube channels, typical is the superior/high value of TCW/TCV). What are the reasons for that?

Turkish Airlines builds their YouTube strategy on creating generally short (up to 1 minute) videos, which are catchy, with slow calm background music. Their videos use sports stars (like football or basketball players Messi, Drogba or Kobe Bryant), also use life stories and try to create an impression.

LATAM Airlines YouTube channel is based on the world destinations presentation. The channel's specificity is that the most viewed videos get a big number of dislikes in comparison to other airlines.

AirAsia and WestJet create videos with the intention of impressing the viewer, motivate the viewer to fulfil their dreams, and they often use celebrities in their videos. AirAsia tries to impress with 360-degree videos and has special sections for these videos. WestJet uses sports stars (baseball), and emphasize in its presentation destinations.

Emirates shows $360^{\circ}$ videos and panoramic views and uses sports football stars and sport sponsoring. Safety videos, made in an interesting way, using teams of stylishly clad air hostesses on stadia, are popular, too.

Air France, KLM, and SpiceJet evince weak positive correlations between subscriber growth and interactions as well as likes and dislikes. Viewers of those channels do not want to interact that much as those on strong channels. This is surprising especially for the systematically structured and built KLM YouTube channel. KLM presentation on YouTube emphasizes the company services and its external relations (in particular environmentally friendly policy). The public is included in YouTube channel creation by means of selfie videos, created as panoramic $360^{\circ}$ views of visited destinations. Air France typically focus on image and impression, offer a lot of animated cartoons aimed at children as well as adults, and provide explanations concerning their service technology.

The weakest or no correlation with subscriber growth and interactions is typically for comments. While there is a correlation between 0.65 and 0.55 for channels with active users, there is weak or no correlation for channels with a high content of passive users.

The study of a success rate of airlines YouTube channels could have been more detailed if the authors would have known the amount of money that the selected airlines 
invested in marketing targeted on YouTube. It is very difficult to find out how much money the selected airlines invest in an advertisement in main social media such as Facebook, Twitter, Instagram and YouTube, and how many of their subscribers are generated through this marketing. Anyway, companies should primarily target making successful video types, the amount of invested money may not be as significant as creating catchy contents, and the focus on stable growth with some irregularly viral videos, because in some cases only a few videos create the vast majority of channel total views.

It is also important to mention that some channels are more effective and successful than others (for example KLM) because they are working flexibly with trends like challenges, $360^{\circ}$ videos, modern technology, social media posts about actual news etc.

\section{Conclusion}

One of the objectives of this study was to find suitable metrics for assessing the success rate of airlines YouTube channels. The success rate of airline YouTube channels is assessed by means of their current static characteristics, including total number of views and number of subscribers, the dynamics of their development, growth in their subscribers, and rate of video content change. Correlation analysis proved to be extremely useful in determining suitable success rate metrics and their mutual relations, as well as in determining conditions under which the channels are successful.

This study validates preliminary results of Zelenka and Hruška (2018), indicating, that all airline companies typically create and present on YouTube short videos, typically under 5 minutes. The best company contributions on YouTube ranged from $30-60$ sec. For successful airlines, YouTube channels typically use sports stars and other celebrities in their videos, (which is in line with Khan, 2017), show service quality and create impressions. These could be the most important factors for running a successful airline YouTube channel as well as YouTube channels dedicated to destinations, hotels and hotel chains and other tourism service providers. This extended research validates other Zelenka and Hruška (2018) results - the significance of addressing the viewer's emotions and motivating them to interact in the form of likes or comments.

\section{Acknowledgment}

This work was supported by the FIM UHK under Grant of Specific Research Project "Information and knowledge management and cognitive science in tourism". 


\section{References}

Alagöz, S. B., \& Ekici, N. (2014). Experiential Marketing and Vacation Experience: The Sample of Turkish Airlines. Procedia - Social and Behavioral Sciences, 150, 500-510.

Alexa (2017). The top 500 sites on the web. Retrieved June 25, 2017 from http:/ /www.alexa.com/ topsites.

Alizadeh, A., \& Isa, R. M. (2014). An examination of use of social media in destination marketing. In Proceedings of the First Asia-Pacific Conference on Global Business, Economics, Finance and Social Sciences (AP14Singapore Conference), Singapore, 1-3 August 2014.

Alizadeh, A., \& Isa, R. M. (2015). The use of social media in destination marketing: An exploratory study. Turizam, 63(2), 175-192.

Camarero, C., \& José, R. S. (2011). Social and attitudinal determinants of viral marketing dynamics. Computers in Human Behavior, 27(6), 2292-2300. DOI: 10.1016/j.chb.2011.07.008.

Dionyssopoulou, P., Pridezi, A.-E., \& Mylonakis, J. (2014). Visual Communication Management Technologies in Promoting Tourism Destinations. International Journal of Management Technology, 2(1), 29-44.

Felix, R., Rauschnabel, P. A., \& Hinsch, C. (2017). Elements of strategic social media marketing: A holistic framework. Journal of Business Research, 70, 118-126, DOI: 10.1016/j.jbusres.2016.05.001.

Hautz, J., Füller, J., Hutter, K., \& Thürridl, C. (2014). Let Users Generate Your Video Ads? The Impact of Video Source and Quality on Consumers' Perceptions and Intended Behaviors. Journal of Interactive Marketing, 28(1), 1-15. DOI: 10.1016/j.intmar.2013.06.003.

Hay, B. (2010). Twitter Twitter - But who is listening? A review of the current and potential use of Twittering as a tourism marketing tool. In CAUTHE 2010 20th International Research Conference: “Challenge the Limits”, February 2010, University of Tasmania.

Hays, S., Page, S. J., \& Buhalis, D. (2013). Social media as a destination marketing tool: its use by national tourism organisations. Current Issues in Tourism, 16(3), 211-239. DOI: $10.1080 / 13683500.2012 .662215$.

Hofacker C. F., \& Belanche, D. (2016). Eight social media challenges for marketing managers. Spanish Journal of Marketing - ESIC, 20(2), 73-80. DOI: 10.1016/j.sjme.2016.07.003.

Hoogeveen, M. (1997). Toward a Theory of the Effectiveness of Multimedia Systems. International Journal of Human-Computer Interaction, 9(2), 151-168. DOI: 10.1207/s15327590ijhc0902_4.

Hruška, J., \& Pásková, M. (2018). How do the National Tourism Organizations use the social media? E+M Economics and Management. (In print).

IATA (2016). WATS 2016. Retrieved June 25, 2017 from http://www.iata.org/docx/WATS_2016infographic.pdf.

IATA (2017). Current IATA Airline Members. Retrieved June 25, 2017 from http://www.iata.org/ about/members/Pages/airline-list.aspx?All=true.

Ishida, K., Slevitch, L., \& Siamionava, K. (2016). The Effects of Traditional and Electronic Wordof-Mouth on Destination Image: A Case of Vacation Tourists Visiting Branson, Missouri. Administrative Sciences, 6(4), 1-17. DOI: 10.3390/admsci6040012.

Khan, G. F., \& Vong, S. (2014). Virality over YouTube: an empirical analysis. Internet Research, 24(5), 629-647. DOI: 10.1108/IntR-05-2013-0085.

Khan, M. L. (2017). Social media engagement: What motivates user participation and consumption on YouTube? Computers in Human Behavior, 66, 236-247. DOI: 10.1016/j.chb.2016.09.024.

Királová, A., \& Pavlíčeka, A. (2015). Development of Social Media Strategies in Tourism Destination. Procedia - Social and Behavioral Sciences, 175, 358-366. 
Kladou, S., \& Mavragani, E. (2015). Assessing destination image: An online marketing approach and the case of TripAdvisor. Journal of Destination Marketing E Management, 4(3), 187-193. DOI: 10.1016/j.jdmm.2015.04.003.

Law, R., Buhalis, D., \& Cobanoglu, C. (2014). Progress on information and communication technologies in hospitality and tourism. International Journal of Contemporary Hospitality Management, 26(5), 727-750. DOI: 10.1108/IJCHM-08-2013-0367.

Leung, D., Law, R., van Hoof, H., \& Buhalis, D. (2013). Social Media in Tourism and Hospitality: a Literature Review. Journal of Travel $\mathcal{E}$ Tourism Marketing, 30, 3-22. DOI: $10.1080 / 10548408.2013 .750919$.

Lily, L., Yuan, W., \& Lifeng, H. (2013). Marketing via social media: a case study. Library Hi Tech, 31(3), 455-466. DOI: 10.1108/LHT-12-2012-0141.

Litvin, S. W., Goldsmith, R. E., \& Pan, B. (2008). Electronic word-of-mouth in hospitality and tourism management. Tourism Management, 29(3), 458-468. DOI: 10.1016/j.tourman.2007.05.011.

Miguéns, J., Baggio, R., \& Costa, C. (2008). Social media and Tourism Destinations: TripAdvisor Case Study. IASK ATR2008 (Advances in Tourism Research 2008), Aveiro, Portugal, May. 26-28.

Mukherjee, A., \& Nagabhushana, M. (2016). Role of Social Media in Tourism Marketing. International Journal of Science and Research, 5(6), 2026-2033, DOI: 10.21275/v5i6.NOV1647761.

Munar, A. M., \& Jacobsen, J. K. S. (2014). Motivations for sharing tourism experiences through social media. Tourism Management, 43, 46-54. DOI: 10.1016/j.tourman.2014.01.012.

Nezakati, H., Amidi, A., Jusoh, Y. Y., Moghadas, S., Aziz, Y. A., \& Sohrabinezhadtalemi, R. (2015). Review of Social Media Potential on Knowledge Sharing and Collaboration in Tourism Industry. Procedia - Social and Behavioral Sciences, 172, 120-125.

Pan, B., \& Crotts, J. (2012). Theoretical models of social media, marketing implications, and future research directions. In M. Sigala, E. Christou, \& U. Gretzel (Eds.), Social Media in Travel, Tourism and Hospitality: Theory, Practice and Cases (pp. 73-86). Surrey, UK: Ashgate.

Reino, S., \& Hay, B. (2011). The Use of YouTube as a Tourism Marketing Tool. In Proceedings of the 42nd Annual Travel EO Tourism Research Association Conference, London, Ontario, Canada, pp. $42-53$.

Socialbakers. (2017a). Brands YouTube statistics - Airlines. Retrieved from https://www.socialbakers. com/statistics/YouTube/channels/brands/airlines/.

Socialbakers. (2017b). Channels comparison method. Part of SW commercial version. Retrieved from https://www.socialbakers.com.

Sotiriadis, M. D., \& van Zyl, C. (2013). Electronic word-of-mouth and online reviews in tourism services: the use of twitter by tourists. Electron Commer Res, 13: 103. DOI: 10.1007/s10660-0139108-1.

Statista. (2017a). Statistics and facts about YouTube. Retrieved June 25, 2017 from https:/ /www.statista.com/topics/2019/YouTube/.

Statista. (2017b). Fastest viral videos as of October 2015. Retrieved June 25, 2017 from https://www. statista.com/statistics/220391/fastest-viral-videos-to-reach-100-million-hits/.

Tussyadiah, I, P., \& Fesenmaier, D. R. (2009). Mediating Tourist Experiences: Access to Places via Shared Videos. Annals of Tourism Research, 36(1), 24-40. DOI: 10.1016/j.annals.2008.10.001.

Urry, J. (2012). Social networks, mobile lives and social inequalities. Journal of Transport Geography, 21, 24-30. DOI: 10.1016/j.jtrangeo.2011.10.003.

Xiang, Z., \& Gretzel, U. (2010). Role of social media in online travel information search. Tourism Management, 31(2), 179-188. DOI: 10.1016/j.tourman.2009.02.016. 
Xiang, Z., Du, Q., Ma, Y., \& Fan, W. (2017). A comparative analysis of major online review platforms: Implications for social media analytics in hospitality and tourism. Tourism Management, 58, 51-65. DOI: 10.1016/j.tourman.2016.10.001.

YouTube. (2017a). Turkish Airlines. Retrieved June 25, 2017 from https://www.YouTube.com/ user/TURKISHAIRLINES.

YouTube. (2017b). Air France. Retrieved June 25, 2017 from https://www.YouTube.com/user/ airfranceonair.

YouTube. (2017c). KLM. Retrieved June 25, 2017 from https://www.YouTube.com/user/ KLMRoyalDutchAirline.

YouTube. (2017d). Emirates. Retrieved June 25, 2017 from https://www.YouTube.com/user/EMIRATES.

YouTube. (2017e). WestJet. Retrieved June 25, 2017 from https://www.YouTube.com/user/ WestJet.

YouTube. (2017f). LATAM Airlines. Retrieved June 25, 2017 from https://www.YouTube.com/ user/tam.

YouTube. (2017g). AirAsia. Retrieved June 25, 2017 from https://www.YouTube.com/user/airasia.

YouTube. (2017h). Pegasus Airlines. Retrieved June 25, 2017 from https://www.YouTube.com/ user/flymepegasus.

YouTube. (2017i). SpiceJet. Retrieved June 25, 2017 from https://www.YouTube.com/user/flyspicejet.

YouTube. (2017j). JetBlue. Retrieved June 25, 2017 from https://www.YouTube.com/user/jetblue.

YouTube. (2017k). China Southern Airlines. Retrieved June 25, 2017 from https://www.YouTube. com/channel/UCePhkrySwUaAPFunrRtnwRg.

YouTube. (20171). United Airlines. Retrieved June 25, 2017 from https://www.YouTube.com/user/ united.

YouTube. (2017m). Lufthansa. Retrieved June 25, 2017 from https://www.YouTube.com/user/ Lufthansa.

YouTube. (2017n). Ryanair. Retrieved June 25, 2017 from https://www.YouTube.com/user/RyanairNews.

YouTube. (2017o). American Airlines. Retrieved June 25, 2017 from https://www.YouTube.com/ user/americanairlines.

YouTube. (2017p). British Airways. Retrieved June 25, 2017 from https:/ / www.YouTube.com/user/ FlyBritishAirways.

YouTube. (2017r). Delta Airlines. Retrieved from https://www.YouTube.com/user/DeltaAirLines.

YouTube. (2017s). Southwest Airlines. Retrieved June 25, 2017 from https://www.YouTube.com/ user/NutsAboutSouthwest.

Zelenka, J., \& Hruška, J. (2018). YouTube in Airlines Marketing. In Proceedings of Hradec Economic Days 2018, pp. 514-526, ISSN 2464-6059.

Zeng, B., \& Gerritsen, R. (2014). What do we know about social media in tourism? A review. Tourism Management Perspectives, 10, 27-36. DOI: 10.1016/j.tmp.2014.01.001. 